\title{
Five Decades of Research on Urban Poverty: Main Research Communities, Core Knowledge Producers, and Emerging Thematic Areas
}

\begin{abstract}
Urban poverty represents one of the greatest and most urgent challenges that modern society is facing. The criticality of this global issue is represented by a rapidly growing body of academic literature which aims to explain the dynamics of urban poverty and promote effective and enduring solutions. However, despite many years of research, no studies have been conducted yet which reveal and analyze the overall intellectual structure of the urban poverty research field. In light of this gap, a bibliometric study was undertaken of 52 years of scientific literature on urban poverty (1965-2017). The bibliometric study combines author citation analysis and text-mining techniques to map the main research communities and core knowledge producers which are shaping the urban poverty research field and to identify the thematic areas that these communities are focusing attention on. The results of this investigation reveal a significant growth in the volume of academic literature produced post-1990, which is mainly driven by the collaborative efforts of five research communities, each of whom are seen to focus attention on a specific thematic area: (A) Policy-oriented research; (B) Urban poverty concentration; (C) The rise of poverty in Chinese cities; (D) Youth-behavioral and mental-health aspects of urban poverty; and (E) Urban poverty and health in the Sub-Saharan and Asian slum areas. The practical relevance and scientific contribution of this study is evidenced in its capacity to assist those actors working to alleviate urban poverty, in particular research communities, governmental and inter-governmental institutions, and funding bodies. In addition to help them grasp the overall intellectual structure of the urban poverty research field, the insight offered by this study is instrumental in supporting the articulation of a global, action-oriented agenda for future interdisciplinary research on urban poverty.
\end{abstract}

Keywords: urban sustainability; urban poverty; bibliometrics; network analysis; text mining; research communities; core knowledge producers; thematic areas

\section{Introduction}

Eradicating urban poverty in all its forms and dimensions is a key global challenge and one of the main priorities of the United Nations' New Urban Agenda. Urban poverty is a complex phenomenon, which is undermining the sustainable development of a growing number of cities, regions and countries all over the world. Systemic changes and sustainable development policies are required to reaffirm equality and eliminate the many issues that the nature of urban poverty poses for housing, natural environment, sanitation, health, education, social inclusion and security, livelihoods and the special needs of vulnerable groups (Ahmad and Puppim de Oliveira, 2015; Hilson et al., 2018; United Nations, 2015; 2017).

A significant body of academic literature has been developed in an attempt to explore and understand the complex nature and dynamics of urban poverty. According to Scopus, one of the world's largest databases of peer-reviewed academic literature, more than 1,500 publications on urban poverty have been produced during the last five decades. However, to date, no studies have been conducted to visualize and analyze the overall intellectual structure of the urban poverty research field.

This shortcoming is revealed by the limited extent of previous bibliometric studies undertaken within the domain of urban poverty. The first analysis is conducted by Zuccala and Van Eck (2010), who investigate the evolution of urban poverty research and its disciplinary distribution 
during a 28-year period (1980-2008). This line of investigation continues with Hassan et al. (2014) and Sweileh et al. (2016). The former analyzes ten years of research on sustainable development (2000-2010), in which urban poverty emerges as a sub-area, performing a comparison of strengths and weaknesses between different institutions. The latter, by analyzing the medicinerelated publications on poverty published between 2005 and 2015, demonstrates that a significant proportion of urban poverty literature has been published in medical journals and exposes its importance through a global health perspective. Some additional studies using bibliometrics have also been conducted which identify underlying links between knowledge spillovers and emerging aspects within the existing urban poverty literature, focusing on issues of urban sprawl (Zeng et al., 2014; Rosni and Noor, 2016), urban resilience (Meerow et al., 2016), and regional inequalities (Cavanaugh and Breau, 2017).

The bibliometric analysis that this paper reports on aims to build and expand upon the findings of the abovementioned research, leading to an improved understanding of the urban poverty research field and current research paths shaping its intellectual structure. By combining two bibliometric analysis techniques, i.e. author citation analysis and content analysis, this study: (1) exposes the overall intellectual structure of the urban poverty research field resulting from 52 years of publication output, from the beginning of 1965 to the end of 2017; (2) map the research communities investigating this subject; and (3) reveal the thematic areas that each community is focusing attention on, pointing out the factors that the existing scientific literature either identifies as relevant for poverty alleviation or does not take into account.

The practical relevance and scientific contribution of this study is evidenced in its capacity to assist those actors working to alleviate urban poverty, in particular research communities, governmental and inter-governmental institutions, and funding bodies. In addition to help them grasp the overall intellectual structure of the urban poverty research field, the insight offered by this study is instrumental in ensuring that a global, action-oriented agenda for future interdisciplinary research on urban poverty is correctly articulated. With the overlapping of many national and international research programs on urban poverty reduction, there is a risk of mismanaging resources due to unnecessary duplication of effort and unawareness of pre-existing evidence. In addition, with the absence of a holistic and comprehensive view of the research field, outstanding issues can remain undetected.

At present, there is no global research agenda in place to address urban poverty (Fox and Goodfellow, 2016). An appropriately coordinated global response to this issue would increase resource efficiency and maximize the impact of collaborative and interdisciplinary research efforts, while ensuring that such efforts are correctly oriented towards addressing top priorities established in the framework of national and international sustainable development strategies (Haddad et al., 2016; Hanefeld et al., 2017; Villaveces et al., 2010; Grott et al., 2017). However, as the lessons drawn from the practice demonstrates (Alahdab and Murad, 2019; Driessen et al., 2015; Wolffers and Adjei, 1999), the formulation of a global research agenda on urban poverty must be predicated on a clear understanding of the intellectual structure underpinning the research field.

The paper is organized in the following sections. Section 2 reports on the methodology deployed to conduct both the author citation network analysis and the text mining process necessary to complete the content analysis. In addition, it provides a detailed description of the data processing phase, the results of which are presented in Section 3. The results of the bibliometric analysis made it possible to investigate the urban poverty research network and capture five main communities of authors, along with the thematic areas they each cover and the core knowledge producers. A thorough discussion of the research communities and their thematic areas is provided in Section 4, whilst Section 5 concludes the paper by summarizing the insight and contribution which this paper offers to the researchers, policy makers, and funding institutions whose collaborative efforts are contributing to a better understanding into one of the most pressing societal challenges of the current age. 


\section{Research methodology}

The intellectual structure of any research field can be considered as a puzzle of individual units (scientific publications), which are grouped by way of subject-related repositories (databases) and produced through the collective effort of a large community of scholars (authors). To analyze the intellectual structure of a research field with bibliometric methods, these scientific publications need to be identified, collected, and then used to extract the raw data necessary to conduct the investigation (De Bellis, 2009; Small and Griffith, 1974). For this reason, such publications are defined as source documents (Casillas and Acedo, 2007; Mora and Deakin 2019; Mora et al., 2017; 2019; Small and Crane, 1979).

This bibliometric study was carried out by using 1,641 source documents, which represent all the publications relating to the field of urban poverty over a 52-year period. The source documents were extracted from Scopus, by means of a keyword search aiming at identifying all the academic literature related to urban poverty published between 1965 and 2017. The source literature was found by running the following search query: TITLE-ABS-KEY ("urban poverty" OR "urban deprivation"). The publications obtained cover a period of 5 decades, from the beginning of 1965 to the end of 2017, and includes journal articles, books, book chapters, conference papers, editorials, and reviews. A breakdown of the source documents by type is presented in Figure 1 .

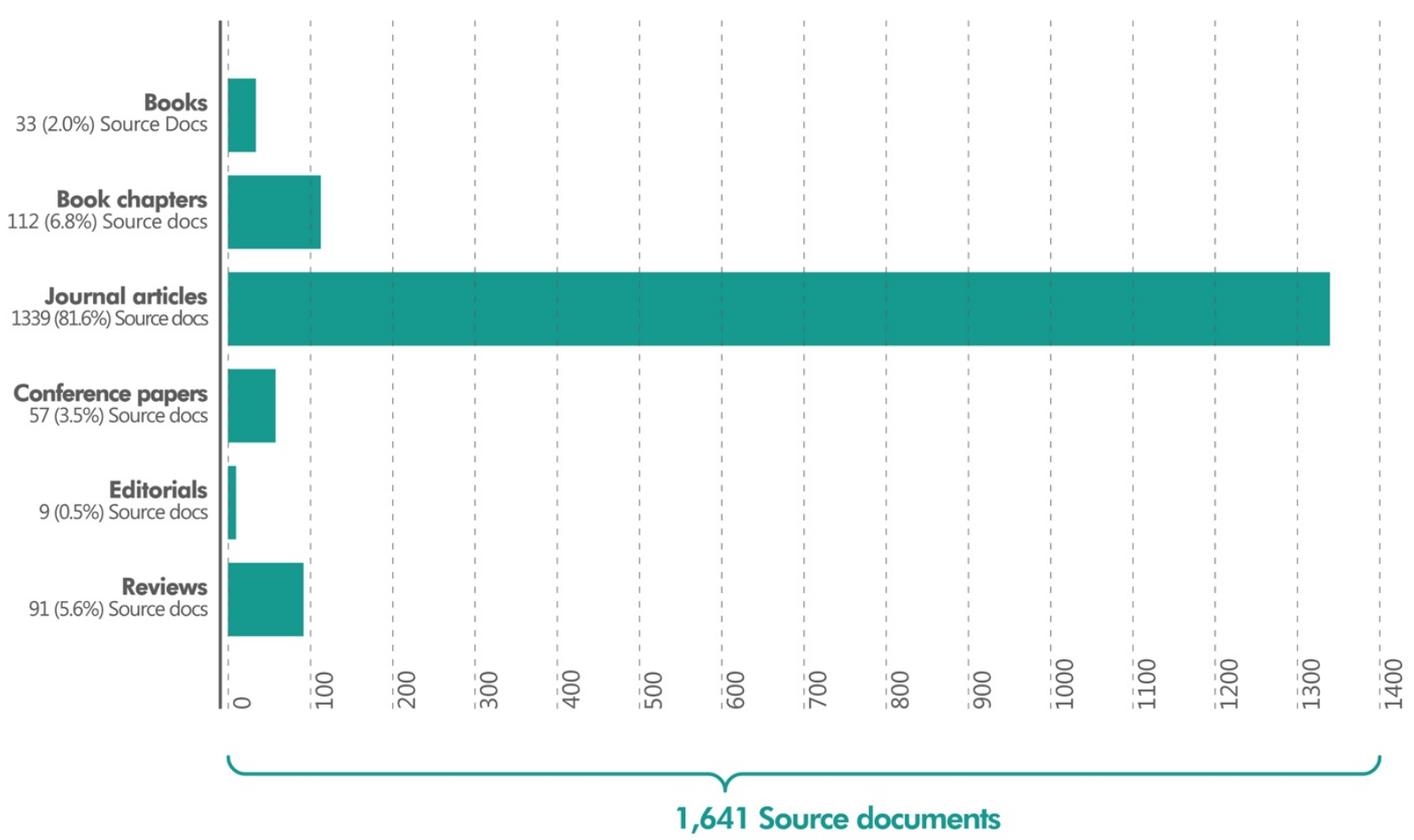

Figure 1. Source documents by type

In any bibliometric analysis, it is essential to check for errors in the extracted dataset (Adam, 2002), therefore, a manual check was performed to identify any mistakes in the data collected or the presence of inadequate records, i.e. records that were duplicates ${ }^{1}$. In the dataset, the following data was listed for each source document: publication title; authors and affiliations; year of

\footnotetext{
1 The search has resulted in 1,705 records. However, after performing the manual check, 64 of these records (3.8\% of the total) were considered inadequate, and therefore excluded from the sample.
} 
publication; keywords; document type; abstract; and cited references, which were necessary to undertake the author citation network analysis. All the data was collected directly from Scopus, excluding the references, which have been extracted manually from the source documents in order to improve the reliability and validity of the data.

After completing the data collection phase, the data was then uploaded onto the open-source software Gephi, which was deployed to perform the author citation analysis and to visualize the network of authors who are active within the research domain. The author citation network analysis considered, firstly, the authors responsible for producing the source documents $(2,574$ authors) and, secondly, the citations listed within these publications (17,375 citations).

The author citation network was analyzed in order to establish the intellectual exchange between authors, creating communities of authors with similar research interests. The identification of such communities in a network involves data clustering, where each node within the network is attributed to a cluster. This data processing can be achieved either through spectral clusteringbased techniques, or by applying network modularity optimization approaches (Porter et al., 2009; Fortunato, 2010). However, in considering these two alternative options, network modularity optimization has proven to be more suitable for community detection in large-scale networks (De Meo et al., 2011) and was therefore selected for investigating the community structure inside the derived author citation network.

According to Newman (2004b), modularity can be expressed as:

$$
Q=\frac{1}{2 m} \sum_{i, j}\left[A_{i j}-\frac{k_{i} k_{j}}{2 m}\right] \delta\left(c_{i}, c_{j}\right)
$$

Where:

- $\quad A_{i j}$ is the weight of the edge between $i$ and $j$,

- $\quad k_{i}=\sum_{j} A_{i j}$ is the sum of the weights of the edges that are attached to vertex $i$,

- $\quad c_{i}$ refers to the community to which vertex $i$ is assigned,

- $\delta(u, v)$ is the $\delta$-function which is 1 if $u=v$ and 0 otherwise, and

- $\quad m=\frac{1}{2} \sum_{i j} A_{i j}$

In the existing literature, several algorithms for network modularity optimization have been developed by using different methodological approaches, such as: agglomerative hierarchical clustering (Clauset et al., 2004; Newman, 2004a); extremal optimization (Duch and Arenas, 2005); simulated annealing (Guimerà et al., 2004; Reichardt and Bornholdt, 2006); spectral optimization (Newman, 2006a, 2006b); mean field annealing (Lehmann and Hansen, 2007); and conformational space annealing (Lee et al., 2012). However, most of these algorithms are unsuitable for analyzing the structure of large and complex networks. Instead, a method commonly adopted for such purposes is the Louvain algorithm (Emmons et al., 2016; Glänzel and Thijs, 2017; Gómez-Núnez et al., 2014; Yu et al., 2017), a large-scale modularity optimization algorithm designed by Blondel et al. (2008).

Consequently, Blondel et al. (2008)'s distributed clustering algorithm was deployed to analyze the modularity of the author citation network. Given that modularity expresses the density of the edges inside derived communities, the Louvain algorithm uses this measure as the baseline indicator to split large networks in sub-communities of interconnected entities. Initially, the algorithm treats each node as a separate entity, and it subsequently detects small local communities by bringing nodes together. The structure of these communities is shaped through short heuristic movements which progressively assign individual nodes to a specific community based on their degree of association with the other nodes belonging to the overall network (Waltman and van Eck, 2013). Nodes of the same community are represented by a high density of connections, whereas their 
relationship with nodes belonging to other modules is characterized by sparse connectivity (McSweeney, 2009).

After completing the process, in order to identify the most influential authors in each of the main communities, a degree centrality analysis was performed in Gephi, by measuring the weighted in-degree of each node. The weighted in-degree of a node determines the influence of the authors within the sub-networks they belong to. This measure is based on the number of inbound links held by each node. The higher the number of inbound links, the higher the number of citations that an author's work has received, and therefore its influence. The authors with the highest weighted in-degree are considered as core knowledge producers.

Finally, the key thematic areas covered by the main communities were identified by applying text mining techniques in $\mathrm{R}$ to the abstracts of the source documents. Word frequency and cooccurrence were used as the main indicators for the topic-identification process in the main communities. The tm package in $\mathrm{R}$ was used for calculating both word frequency and cooccurrence between terms in every single case (Feinerer and Hornik 2017; Wiedemann, 2016; Niekler et al., 2014; Feinerer et al., 2008). Following a sentence-segmentation model, the abstracts were deconstructed into sentences, with each sentence treated as a separate document. Subsequently, the results were aggregated by community to identify the co-occurrence patterns and overall frequency of the terms extracted within each set of source documents. Loglikelihood has been chosen as the key measure to check the significance of co-occurrence between terms (Niekler et al., 2014).

This methodological approach was proven effective in achieving the objectives of this bibliometric study. However, in order to interpret the results of the study, it is important to acknowledge the presence of two methodological limitations.

Firstly, the use of a single database to gather the source literature may have resulted in some relevant academic publications on urban poverty being undetected. Various coverage comparison studies demonstrate that scholarly databases retrieve different sets of publications when the same search query is processed and their level of coverage tends to change depending upon the subject under investigation (Ball and Tunger, 2006; Bar-Ilan, 2018; Durán Sánchez et al., 2017; Halevi et al., 2017; Martín-Martín et al., 2018). To overcome this limitation and identify the most suitable database for this bibliometric study, Scopus and Web of Science (WoS) were both tested to establish their coverage of the urban poverty domain. The initial keyword search was performed in both databases, which represent two of the main sources of bibliometric data currently available (Mongeon and Paul-Hus, 2016). Scopus was found to offer a broader coverage of literature, sourcing 503 additional titles.

The second limitation regards the exclusion of Google Scholar from the data collection phase. This web-based academic search engine does not offer the same search and filtering features available in Scopus and WoS (Shultz, 2007). In addition, it is also affected by additional functional restrictions, including the impossibility to directly export results and absence of quality control mechanisms (Haddaway et al., 2015; Halevi et al., 2017). For these reasons, Google Scholar was considered unsuitable for supporting the analysis and, as a consequence, grey literature ${ }^{2}$ was excluded from the study. Whilst this study focused attention on gold standard, peer-reviewed literature, it would have been useful to investigate whether the grey literature on urban poverty had an influence on the academic debate and the intellectual structure of the research domain. Unlike Google Scholar, neither Scopus nor Web or Science index grey literature (Gusenbauer, 2019; Haddaway et al., 2015) and therefore this line of enquiry was ruled out.

\footnotetext{
${ }^{2}$ Grey literature can be defined as literature which is published without a formal peer-review process and "is not controlled by commercial publishers i.e., where publishing is not the primary activity of the producing body" (Schopfel, 2010).
} 


\section{Results}

A schematic representation of the overall network is given in Figure 2, in which the authors are visualized as nodes, while the edges represent the connecting elements. The weight of every edge is directly proportional to the number of citations connecting two nodes. The analysis of the network enabled the identification of five highly-populated intra-network communities of authors, which are visualized in yellow, blue, purple, green and red. Overall, these communities represent $86 \%$ of all authors engaged in research into urban poverty. The top 10 core knowledge producers of each research community are listed in Table 1, along with their affiliations and degree of centrality.

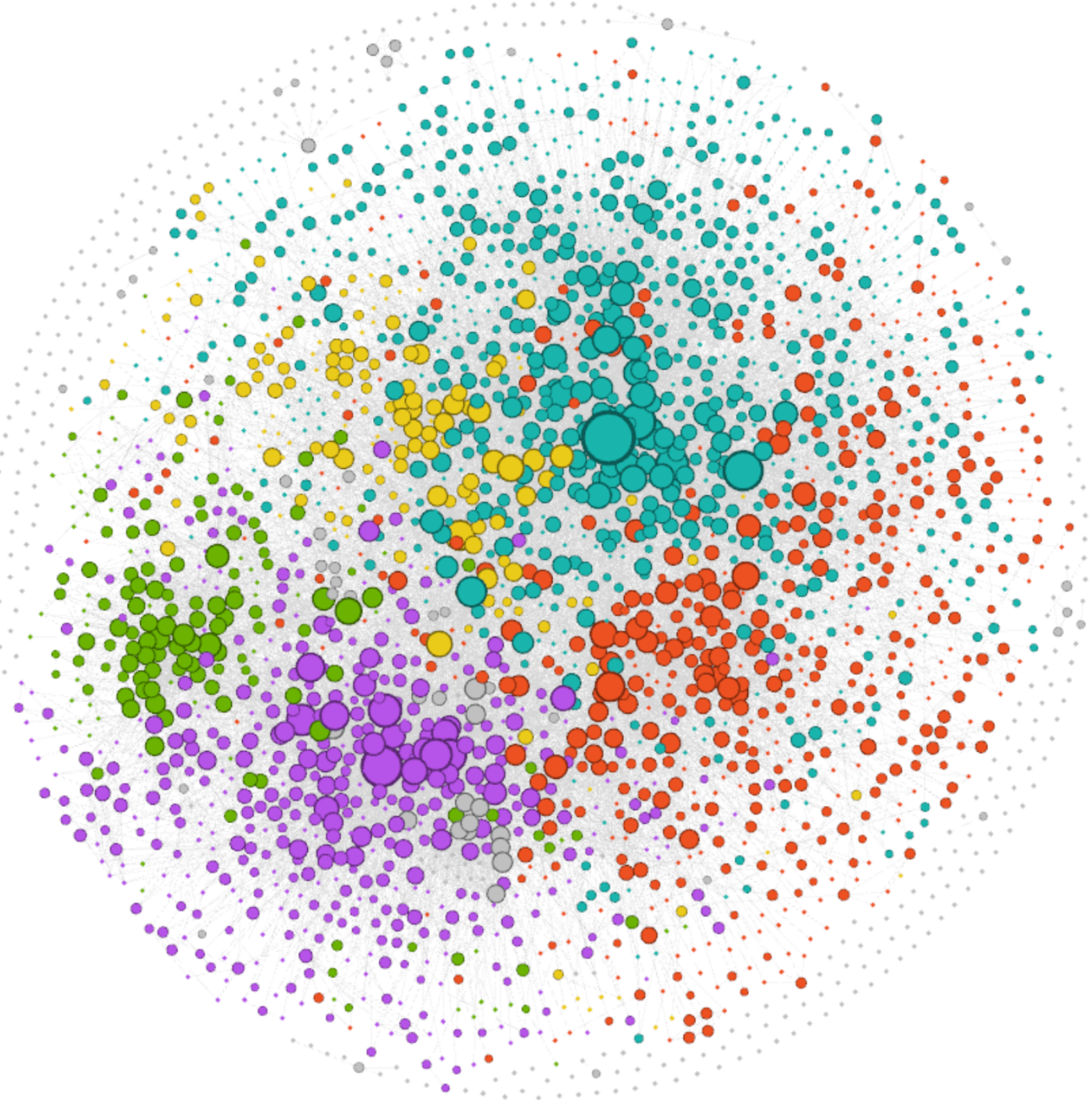

Figure 2. The author citation network and its highly-populated intra-network communities of authors, which are visualized in light blue (Community A), purple (Community B), red (Community 
C), green (Community D), and yellow (Community E). The diameter of the nodes is directly proportional to their degree of centrality (weighted in-degree).

\begin{tabular}{|c|c|c|c|c|}
\hline Community & $\begin{array}{l}\text { Core Knowledge } \\
\text { producer }\end{array}$ & Affiliation & Country & $\begin{array}{l}\text { Weighted } \\
\text { in-degree }\end{array}$ \\
\hline \multirow[t]{12}{*}{ Community $\mathrm{A}$} & United Nations & United Nations & USA & 787 \\
\hline & Ravallion M. & The World Bank & USA & 219 \\
\hline & Satterthwaite D. & $\begin{array}{l}\text { International Institute for Environment and } \\
\text { Development }\end{array}$ & UK & 171 \\
\hline & Moser C. & The World Bank & USA & 124 \\
\hline & Mitlin D. & University of Manchester & UK & 115 \\
\hline & Rakodi C. & University of Birmingham & UK & 110 \\
\hline & Harvey D. & City University of New York & USA & 100 \\
\hline & Ruel M. & International Food Policy Research Institute & USA & 81 \\
\hline & Gilbert A. & University College London & UK & 72 \\
\hline & McGranahan G. & $\begin{array}{l}\text { International Institute for Environment and } \\
\text { Development }\end{array}$ & UK & 68 \\
\hline & Haddad L. & International Food Policy Research Institute & USA & 68 \\
\hline & Hardoy J. & $\begin{array}{l}\text { International Institute for Environment and } \\
\text { Development }\end{array}$ & Argentina & 66 \\
\hline \multirow[t]{11}{*}{ Community B } & Wilson W.J. & Harvard University & USA & 247 \\
\hline & Wacquant L. & University of California, Berkeley & USA & 133 \\
\hline & Sampson R.J. & University of Chicago & USA & 129 \\
\hline & Massey D.S. & University of Chicago & USA & 118 \\
\hline & Duncan G.J. & Northwestern University & USA & 110 \\
\hline & Anderson E. & University of Pennsylvania & USA & 89 \\
\hline & Earls F. & Harvard University & USA & 86 \\
\hline & Jargowsky P.A. & University of Texas at Dallas & USA & 83 \\
\hline & Galster G. & Wayne State University & USA & 71 \\
\hline & Newman K. & Harvard University & USA & 69 \\
\hline & Portes A. & Princeton University & USA & 57 \\
\hline \multirow[t]{10}{*}{ Community $\mathrm{C}$} & Khan A. & University of California, Berkeley & USA & 78 \\
\hline & Wang $\mathrm{Y}$. & Chinese National Statistical Bureau & China & 74 \\
\hline & Fan S. & International Food Policy Research Institute & USA & 52 \\
\hline & Riskin C. & City University of New York & USA & 50 \\
\hline & Lanjouw P. & VU University Amsterdam & $\begin{array}{l}\text { Netherla } \\
\text { nds }\end{array}$ & 48 \\
\hline & Zhang X. & International Food Policy Research Institute & USA & 46 \\
\hline & Taylor S. & University of California, Los Angeles & USA & 42 \\
\hline & Sliuzas R. & University of Twente & $\begin{array}{l}\text { Netherla } \\
\text { nds }\end{array}$ & 42 \\
\hline & Wu F. & Cardiff University & UK & 41 \\
\hline & Gustafsson B. & Institute for the Study of Labor (IZA) & Sweden & 41 \\
\hline \multirow[t]{10}{*}{ Community D } & Tolan P.H. & University of Virginia & USA & 51 \\
\hline & Grant K.E. & DePaul University, Chicago & USA & 45 \\
\hline & Evans G.W. & University of California & USA & 41 \\
\hline & Thurm A.E. & National Institute of Mental Health & USA & 39 \\
\hline & Luthar S.S. & Columbia University & USA & 36 \\
\hline & Danziger S. & University of Wisconsin & USA & 34 \\
\hline & Cauce A.M. & University of Washington, Seattle & USA & 31 \\
\hline & Carlson G.A. & Phoenix children's hospital & USA & 28 \\
\hline & Holmbeck G.N. & Loyola University, Chicago & USA & 26 \\
\hline & Gaylord-Harden N.K. & Loyola University, Chicago & USA & 25 \\
\hline
\end{tabular}




\begin{tabular}{|c|c|c|c|c|}
\hline \multirow[t]{10}{*}{ Community $\mathrm{E}$} & Ezeh A. & $\begin{array}{l}\text { African Population and Health Research } \\
\text { Center }\end{array}$ & Kenya & 96 \\
\hline & Harpham T. & The Kenya Medical Research Institute & Kenya & 69 \\
\hline & Shibuya K. & University of Chicago & USA & 64 \\
\hline & Zulu E. & African Institute for Development Policy & Kenya & 48 \\
\hline & Montgomery M.R. & Stony Brook University & USA & 47 \\
\hline & Brockerhoff M. & Population Council & USA & 42 \\
\hline & Agyei-Mensah S. & University of Ghana & Ghana & 37 \\
\hline & Emina J. & $\begin{array}{l}\text { African Population and Health Research } \\
\text { Center }\end{array}$ & Kenya & 32 \\
\hline & Lim S. & University of Michigan & USA & 32 \\
\hline & Kyobutungi C. & $\begin{array}{l}\text { African Population and Health Research } \\
\text { Center }\end{array}$ & Kenya & 31 \\
\hline
\end{tabular}

Table 1. Core knowledge producers in the field of urban poverty.

Table 2 compares some of the key network features of the main research communities and presents the results of the content analysis. Community A represents the most-populated community in the network, containing $32 \%$ of the total nodes and the highest amount of citations (37\%). Both Community B and Community C represent about $20 \%$ of the total number of nodes and citations. Finally, Community $\mathrm{D}$ and Community $\mathrm{E}$ are the smallest sub-networks in the group.

\begin{tabular}{|c|c|c|c|c|c|}
\hline Community & No of nodes & No of edges & Keywords & & Co-occurrence pattern \\
\hline \multirow[t]{10}{*}{ Community A } & \multirow[t]{10}{*}{$832(32.32 \%)$} & \multirow[t]{10}{*}{$6424(36.97 \%)$} & Cities & 958 & Rural Urban \\
\hline & & & Development & 639 & Rural Migration \\
\hline & & & Food & 612 & Insecurity Nutrition \\
\hline & & & Social & 568 & Growth Economic \\
\hline & & & Income & 556 & Insecurity Household \\
\hline & & & Areas & 543 & Urban poverty $\sim$ Reducing \\
\hline & & & Policy & 526 & Urban poverty Growing \\
\hline & & & Rural & 488 & Reduction Programmes \\
\hline & & & Economic & 472 & Rural Peri-urban \\
\hline & & & Households & 446 & Insecurity Peri-urban \\
\hline \multirow[t]{10}{*}{ Community B } & \multirow[t]{10}{*}{$482(18.72 \%)$} & \multirow[t]{10}{*}{$3912(22.52 \%)$} & Social & 312 & Family Life \\
\hline & & & Income & 159 & Family Chronic \\
\hline & & & Economic & 152 & Research Recent \\
\hline & & & Research & 143 & Political Science \\
\hline & & & Cities & 137 & Concentration Geographic \\
\hline & & & Areas & 136 & Family Coping \\
\hline & & & Housing & 127 & Concentrated $\sim$ Urban poverty \\
\hline & & & Public & 123 & Concentrated $\sim$ Spatially \\
\hline & & & Low & 118 & Research $\sim$ Review \\
\hline & & & Neighborhoods & 117 & Family Chicago \\
\hline \multirow[t]{10}{*}{ Community $\mathrm{C}$} & \multirow[t]{10}{*}{$546(21.21 \%)$} & \multirow[t]{10}{*}{3467 (19.95\%) } & Social & 202 & Urban Poverty $\sim$ China \\
\hline & & & Income & 187 & Declined Incidence \\
\hline & & & China & 183 & Rural Migrants \\
\hline & & & Economic & 181 & Rural Areas \\
\hline & & & Rural & 164 & China Reforms \\
\hline & & & Areas & 130 & Rural Roads \\
\hline & & & Cities & 111 & Declined Launched \\
\hline & & & Data & 107 & Major Force \\
\hline & & & Based & 102 & Major Shows \\
\hline & & & Growth & 97 & Suggest Approach \\
\hline
\end{tabular}




\begin{tabular}{|c|c|c|c|c|c|}
\hline \multirow[t]{10}{*}{ Community D } & \multirow[t]{10}{*}{$175(6.80 \%)$} & \multirow[t]{10}{*}{$1527(8.78 \%)$} & Health & 50 & Income Urban \\
\hline & & & Children & 48 & Income Youth \\
\hline & & & Social & 43 & Youth Low \\
\hline & & & Community & 42 & Income $\sim$ Sample \\
\hline & & & Mental & 41 & Youth Violence \\
\hline & & & Youths & 38 & Youth Internalizing \\
\hline & & & Symptoms & 35 & Youth Exposure \\
\hline & & & Living & 33 & Income $\sim$ Examined \\
\hline & & & Risks & 30 & Income Study \\
\hline & & & Low & 29 & African-American Income \\
\hline \multirow[t]{10}{*}{ Community $\mathrm{E}$} & \multirow[t]{10}{*}{$168(6.52 \%)$} & \multirow[t]{10}{*}{1547 (8.90\%) } & Health & 83 & HIV Association \\
\hline & & & Women & 40 & Slum Sexual \\
\hline & & & Areas & 32 & HIV Risk \\
\hline & & & HIV & 28 & HIV Higher \\
\hline & & & Social & 28 & Poor Countries \\
\hline & & & Data & 26 & Risk Lower \\
\hline & & & Rural & 26 & HIV Africa \\
\hline & & & Services & 24 & HIV Sub-Saharan \\
\hline & & & Slum & 23 & Risk Higher \\
\hline & & & Care & 22 & HIV Primary \\
\hline
\end{tabular}

Table 2. Main research communities in the field of urban poverty.

\section{Main research communities and thematic areas in urban poverty research}

Figure 3 shows the growth of publications relating to urban poverty during the period under investigation. As is shown, there are very few documents published before 1980. However, there is a sharp increase in urban poverty research during the 1990s, which could be explained by the rapid expansion of this phenomenon in many US metros and developing countries (Massey and Denton, 1993; Cooke and Marchant, 2006; Hardoy and Pandiella, 2009; López-Morales, 2016). It is important to note that there has been an increase of more than $300 \%$ in the number of publications on urban poverty between the 1980s and the 1990s. Furthermore, this growth trend continues during the next two decades, with $42.47 \%$ of the total number of source documents published between 2010 and 2017.

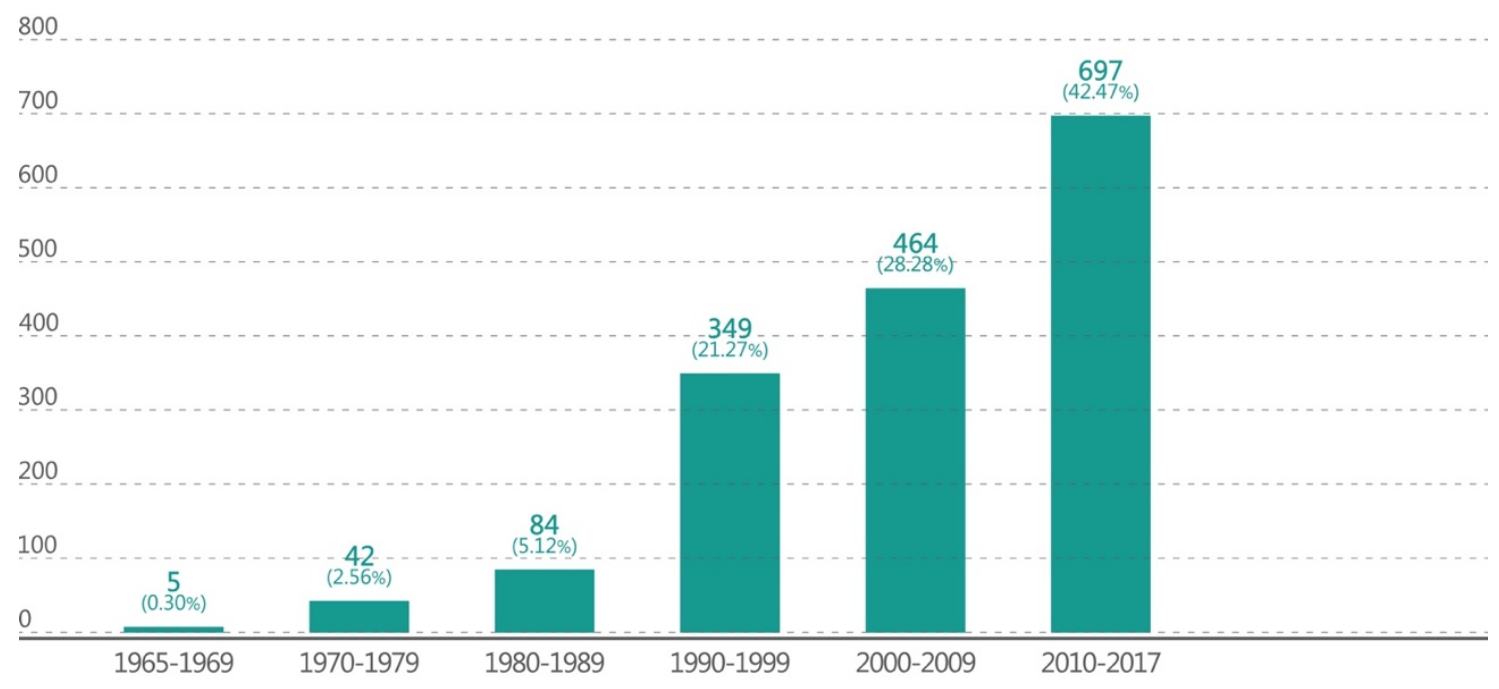

Figure 3. Source documents of this bibliometric study by period of publication 
This significant growth in the volume of publications since the 1990s has been mainly driven by the collaborative efforts of five research communities, each focusing attention on a specific thematic area emerging from the content analysis: (A) policy-oriented research, which exposes and evaluates the policy interventions that the United Nations and The World Bank are championing to alleviate urban poverty; (B) urban poverty concentration, where the collective efforts of North American universities are leading to an improved understanding of the interplay between urban poverty and growing income inequality; $(C)$ the rise of poverty in Chinese cities, where the research resulting from the collaboration between universities in North America, Europe and the Asia-Pacific region suggests China constitutes a case study deserving a specific research path; (D) youth-behavior and mental-health aspects of urban poverty, a research area which is also driven by North American universities; and (E) urban poverty and health in the Sub-Saharan and Asian slum areas, where a strong collaboration between African research institutes and North American universities is evident.

\subsection{Community A: Policy-oriented research}

Policy-oriented research related to urban poverty has focused its attention on identifying methods to alleviate this phenomenon, primarily in developing countries, where urbanization starts to become a parameter that impacts upon the overall poverty formation process (Ravallion, 2002, 2007). Although rural areas have traditionally been most affected by this global issue, migration from rural to urban areas has increased the prevalence of urban poverty, leading to a significant rise of poverty in cities (Abubakar and Dano, 2018; Chigbu, 2012; Mitlin, 2003; De Haan, 1997). The proliferation of urban slums, followed by a rapid deterioration of human settlements, have the primary focus of scholarly attention. Under this framework, the United Nations (UN) and World Bank are committed to exploring such phenomena in highly populated urban areas, trying to identify best practices and policy recommendations that could boost the effectiveness of government initiatives aimed at reducing urban poverty.

In the first Global Report on Human Settlements (United Nations, 1986), the call for a transition from 'normative and regulatory practices' to 'enabling strategies' is significant, illustrating the importance of a more effective policy-design towards urban poverty alleviation. In 1996, the UN recognized this phenomenon as one of the most prevailing trends during the 1980s and early 1990s. Evidence indicated that governance is a key factor, affecting urban poverty conditions to a large extent (United Nations, 1996). Meanwhile, the forces of globalization have played a crucial role in the dynamics of city formation, leading to insufficient institutional capacity and a loss of social justice (United Nations, 2001). In response to this finding, the UN has stated that emphasis should be given to the development of new practices, such as new housing models and poverty alleviating policies that could support the development of poor, urban populations. Thus, the need to expand the range of urban policies towards addressing additional aspects of poverty has been highlighted, including geographical access to jobs, affordable housing conditions and appropriate location of low-income settlements (United Nations, 2003, 2005).

Developing countries have long been the focus of urban poverty studies. Empirical evidence has demonstrated that a high proportion of urban populations in developing countries in Africa, Asia and Latin America, live below the poverty line (Tabatabai and Fouad 1993; Satterthwaite, 1997). Economic restructuring and rapid urbanization have contributed to the proliferation of this phenomenon (Moser et al., 1993), leading to diminished living conditions, including restricted access to safe water, malnutrition and inadequate housing (Harpham and Stephens, 1991; McGranahan, 1991). The set of Millennium and Sustainable Development Goals (United Nations, $2000,2015)$ highlighted the emerging need for alleviating extreme poverty and making cities more inclusive and sustainable. These notions started to influence urban poverty policy, which adopted 
these goals as their baselines (Satterthwaite, 2003a; Ebrahim, 2008; Stein and Horn, 2012; Adebimpe, 2013; Jha and Tripathi, 2015).

Studies focusing on extreme living conditions, specifically in malnutrition, have identified that urban poverty has already had a significant impact in developing countries, and this trend is forecasets to continue (Haddad et al., 1999; Kimani-Murage, 2015; Pryer, 2017). In addition, food insecurity has been approached through different perspectives. In some cases, it is understood as the lack of aggregate supply to urban areas, whereas in other cases it refers to the ability of a household to purchase adequate quantity and quality of food (Maxwell, 1999; Haddad et al., 1999; Ruel, 2000; Tacoli et al., 2013; McFarlane et al., 2014). At the same time, extreme living conditions resulting from urban poverty include additional aspects, such as urban security and violence (Fox and Beall, 2012; Beall et al., 2013; Raleigh, 2015), unemployment as an outcome of economic restructuring (Gilbert, 1995; Beall et al., 2000; Gulyani and Talukdar, 2010) and negative environmental impacts (Bryant, 1993; Satterthwaite, 2003b; Hardoy and Pandiella, 2009).

Given the above, the need to provide an integrated approach towards poverty alleviation, encompassing social, economic, political and environmental aspects, is evident. This requires the use of both qualitative and quantitative analysis to maximize the likelihood of a positive outcome (Wratten, 1995). Evidence-based analysis became a key parameter not only for policy assessment, but also for the formulation of policies aimed at alleviating poverty (Hentschel and Seshagiri, 2000). Comparative studies between different types of urban areas, characterized by diverse levels of economic development, have been used to explore household responses to poverty variations. The results revealed several similarities between these groups, indicating that resilience to poverty depends, to a large extent, on material well-being and social capital (Moser, 1996; Alexandrova et al., 2006).

Within this context, the definition of assets, both tangible and intangible, that poor populations hold has become an alternative policy-design framework. Policy interventions should focus on boosting the effective use of these assets by impoverished populations (Racodi, 1995; Moser, 1998). Strategies focusing on enhancing the existing assets' base might depend on the development of novel urban inclusion practices, strengthening the relationships between local authorities and citizens, as well as reinforcing grassroots organizations (Rakodi, 1995; Booth et al., 1998; Miltin, 2003; Hentschel, 2004). Social network users from urban low-income communities play an essential role in sharing experiences and empowering the ability of poor people to manage diversified portfolios, strengthening the overall resilience of a city (Beall, 1995). Easy access to key services and institutions has also been identified as a critical factor in increasing the opportunities offered to poor people at a local level (Lanjouw and Murgai, 2010).

Finally, recent studies have revealed some additional aspects which the rise of urban poverty has introduced to policy-design processes, referring specifically to the institutional capabilities of a city. Public participation of the urban poor seems to play a key role in the effectiveness of local policies. Encompassing the voices of the urban poor throughout policy-design processes would appear to be a key parameter that enhances institutional capabilities and helps deliver highly democratic arrangements (Devas, 2014). In addition, strengthening collective action is a means to foster successful community-driven initiatives, which could work as complementary policy tools for urban poverty reduction (McGranahan, 2015).

\subsection{Community B: Urban poverty concentration}

One of the first researchers who tried to conceptualize the notion of urban poverty, adopting the controversial term 'underclass', was WJ Wilson in his book 'The Truly Disadvantaged' (1987). According to Wilson (1987), ethnic and gender disparities in the household structure are part of a wider class transformation process that had been occurring in urban areas, leading to a gradual creation of poor areas within the inner city. Meanwhile, broader structural changes and problems 
of regional economies have reinforced the creation of this highly disadvantaged 'underclass'. To this end, policies focusing on alleviating urban poverty should take into consideration the impact of the changing economic structure at a global scale, as well as the racially distinct problems that arise within the inner city (Wilson, 1999).

The emerging 'underclass' phenomenon has been used as the baseline upon which researchers attempted to expand their research and explore the evolution of concentrated urban poverty throughout time, notably in large US and European cities. Urban poverty has changed during the 1970 s and 1980s, towards becoming more spatially concentrated (Small and Newman, 2001). However, the results indicate that despite this increasing trend of poverty segregation during the 1980s, poverty became notably less concentrated during the 1990s (Kingsley and Pettit, 2003). Data also revealed that levels of urban segregation were generally lower in European cities when compared to large US metros (Pacione, 2004; Hunter, 2014), a phenomena attributed to an understanding that the urban poor did not seem to be detached from the middle class in Europe (Musterd, 2005). During the recent years, socio-economic segregation continues to increase, raising issues for political scientists and economists to define its nature and identify its main drivers (Tammaru et al., 2016).

From the earliest studies, the role of individual characteristics and regional variances have been highlighted, giving rise to a set of factors that could affect the evolution of urban poverty. Traditionally, minority ethnic groups experience higher levels of poverty concentration (Jargowsky, 2002). At the same time, issues relating to the family structure, such as male joblessness, teenage motherhood, and single parenthood, contribute significantly to the creation of highly deteriorated neighborhoods, characterized by high levels of crime and increased mortality rates (Massey et al., 1991; Massey and Denton, 1993).

According to Earls (2000), urban poverty is another outcome of increasing income disparity, and thus, broader structural changes might have led to the creation of poverty. Some significant drivers of diversified urban segregation phenomena include: housing market discrimination, access to information on housing, accessibility of jobs and economic processes and structures (Dawkins, 2004; Musterd, 2005; Scott and Storper, 2015; Musterd et al., 2017). One essential parameter, which is closely related to aspects of the political economy, refers to the transition from a Fordist to a post-Fordist economic structure. This structural change has resulted in a significant number of unemployed workers, most of which are low-skilled, and thus, indicating reduced integration opportunities through the labor market channel (Musterd, 2005). The ways in which economic re-structuring has affected poverty formation and concentration relate also to the work of Sassen (1991), who explores the emerging social geography rising from the economic transformations that took place within global cities. One of the main results coming from this exploration is that different types of economic growth promote different types of social forms.

At the same time, from an evolutionary perspective, empirical studies have shown that there is a high correlation between the urban sprawl and the concentration of poverty, throughout the developmental processes of a metropolitan area (Kaserman et al., 2015; Cho et al., 2012; Olvera, 2005). This fact seems to work in favor of the expansion of poverty, exacerbating its effects and limiting at the same time the existing opportunities for the urban poor (Jargowsky, 1996). This discussion reveals the existence of underlying relationships between the expansion of cities and the evolution of poverty in the urban core, compared to suburban areas (Berube and Frey, 2002; Cooke, 2010; Kneebone and Berube, 2013; Cooke and Denton, 2015). In some cases, significant increases in suburban poverty may have resulted in response to the lack of resources needed to overcome the negative effects associated with a rising poor population (Galster, 2007).

The investigation of the neighboring effects arising through poverty concentration is another essential aspect of urban poverty literature in this community of authors. Galster $(1987,2012)$ argues that despite the general decreasing trend in poverty segregation during the 1990s, there has been an increase in the number of areas closer to the point where poverty concentration starts to generate significant local externalities for their neighbors. Given this, the existence of 
neighboring effects related to poverty concentration, might restrict the overall improvement of quality-of-life within urban areas, as it would result in an increased number of areas experiencing moderate levels of poverty (Galster and Mincy, 1993; Friedrichs et al., 2003; Galster, 2005).

In addition to neighboring effects, the investigation of intra-urban migration flows, and their implications have also received attention within urban poverty research. Data availability referring to movements of poor and non-poor immigrants has offered the opportunity to further analyze the evolution of income dynamics within cities (Massey et al., 1994). Selective migration processes, where income levels among incomers to poor neighborhoods are well below those of out-movers, tending to exacerbate poverty rates' variations in urban areas, specifically during economic crisis' periods (Andersson and Hedman, 2016). The synthesis of these in- and out-flows is affected to a large extent by the structure of the local housing markets. To this end, urban housing markets gradually become drivers of poverty segregation, indicating an expansion of the underlying mechanisms that reinforce this phenomenon (Ludwig et al., 2001, 2005; Cooke, 2010; Musterd et al., 2016).

\subsection{Community $\mathrm{C}$ : The rise of poverty in Chinese cities}

China, having experienced radical structural economic reforms since the late 1990s, constitutes a special case. Despite significant income growth during this period, urban poverty has also rapidly increased, affecting large shares of the population (Khan and Riskin, 2001; Xue and Zhong, 2003). Thus, urban poverty research in Chinese cities began to receive significant attention from both policy makers and academics (Gustafsson and Zhong, 2000; Knight and Shi, 2001; Cheng et al., 2002).

According to the existing literature, the sharp rise in China's urban poverty can be attributed to structural transitions, not only in economic terms (e.g. the transition from a planned system to a market system or deregulation of grain prices), but also in the social protection system, leading to a deterioration of the living conditions of the urban poor (Meng et al., 2005, 2007; Wu, 2004; Wang, 2007). More specifically, market restructuring has led to higher unemployment shares, affecting to large extent poor households, that include mainly low-skilled or poorly educated members, as well as female workers (Knight and Xue, 2006; Knight and Song, 2005; Giles et al., 2008; Wang, 2007). At the same time, large households and households with non-working members were found to be the most vulnerable demographic groups within urban areas in China (Meng et al., 2007).

From a policy perspective, poverty alleviation in urban areas was not on the policy agenda from the very beginning, as China's antipoverty program mainly focused on rural areas (Cheng et al., 2002). To this end, China's provision policies, including benefit programs, did not have any noticeable impact in reducing this phenomenon (Riskin and Gao, 2009). Hence, it became necessary to design and implement new social policies based on income redistribution mechanisms, for promoting a more balanced program for economic development in Chinese cities (Wang, 2007). The most well-known example of anti-poverty policy was the Minimum Likelihood Guarantee program in 1999, also known as the dibao program (Chen et al., 2006). The program aimed to provide urban households that were below the poverty line, with a sufficient amount of transfer payment per capita, to bring them out of poverty. However, empirical evidence indicated that the program did not manage to effectively alleviate poverty, as it failed to deliver a significant impact (Chen et al., 2004).

The systemic failures experienced in China have resulted in the rise of new forms of urban poverty in Chinese cities, leading to the creation of a sizeable underclass, institutionally detached in many cases from mainstream urban social groups (Wu, 2004). The emergence of such groups has led to path dependency phenomena, which are linked to the creation of small, but still significant, neighbourhood effects (Liu et al., 2010; Wu et al., 2010a, b). The existing uneven distribution of advantaged and disadvantaged housing tenures in Chinese cities has led to the development of 
a well-established residential geography, which constitutes one of the main catalysts for the pathdependent feature of derived social inequalities (Wu et al., 2010a).

Given the above-mentioned features, it is essential to understand that for the Chinese case someone should not ignore the existing institutional and economic changes that have been taking place during the last decades in China, as it would be impossible to understand and effectively investigate the relationship between growth and urban poverty (Meng et al., 2005).

\subsection{Community D: Youth behavioral and mental health aspects of urban poverty}

A significant proportion of urban poverty literature focuses on the behavioral aspects of this phenomenon. Physical environment is a factor that should not be neglected in urban poverty studies (Evans and English, 2002). Given that income is related to environmental quality, and at the same time environmental quality is positively associated with psychological health outcomes, there seems to be an indirect channel between poverty and human behavioral aspects (Evans and Kantrowitz, 2002). Empirical evidence indicates that people with low socioeconomic status are at increased risk of experiencing depression (Lorant et al., 2003; Mondi et al., 2017) and at the same time, they are less likely to take advantage of mental health services (Wang et al., 2005).

Moreover, poverty disproportionally increases risks and poor outcomes for the urban youth through multiple channels, such as home, school and neighborhood (Cappella et al., 2008; Frazier et al., 2015). Evidence reveals that low-income urban children experience more stressful events compared to their middle-income urban counterparts (Dubow et al., 1991; Attar et al., 1994; Brooks-Gunn et al., 1995; Duncan and Brooks-Gunn, 1999; Murali and Oyebode, 2004). Some additional aspects, regarding the ways in which low-income urban environments affect human flourishing, include issues such as difficulties in educational attainment and achievements (Gonzales et al., 1996; Crowder and South, 2003; Ceballo et al., 2004), as well as the provision of emotional support to other people (McMahon and Luthar, 2007; Abenavoli et al., 2015).

From a policy perspective, the cyclical nature of this relationship indicates that a more comprehensive approach should be adopted towards alleviating this phenomenon, including improvements in the mental health care system that could promote prevention and target young people (Anakwenze and Zuberi, 2013).

\subsection{Community E: Urban poverty and health}

Links between urban poverty and health have also been in the spotlight throughout the existing literature in this field. By looking at the authors included in this community and their main topics, it becomes clear that Sub-Saharan and Asian studies constitute special cases when it comes to health effects due to high urbanization trends, focusing mostly on HIV expansion.

Evidence indicates that there is a complex relationship between urban poverty and HIV, as there is a disproportionate risk of HIV infection among the urban poor populations (Magadi, 2013). With almost one third of the world's urban population living in urban slums conditions, inequalities between slum and non-slum areas are a key factor for the expansion of health infections, such as HIV, due to poor hygiene and sanitation conditions (Elsey et al., 2016). Deterioration of maternal and child health, due to poor living conditions constitute additional vulnerability factors, affecting the evolution of HIV infection, whereas women living in poverty experience higher risks due to gender-based violence and prostitution (Hunter, 2007; Rodrigo and Rajapakse, 2010; Magadi, 2016). Meanwhile, intra-city residential movements, as well as in-migration flows seem to also reinforce this phenomenon, specifically in places with high population density, increased poverty rates and insecurity (Ngigi, 2007; Vearey et al., 2011). 
In terms of policy-design, community-based intervention studies have shown that it is feasible to develop or re-organize long-term health and demographic surveillance systems in urban slum settlements (DeGelder, 2012; van de Vijver et al., 2016). Within this context, essential data could be collected to guide policy interventions focusing on improving the quality-of-life of the urban poor and inform policy-design for effective interventions (Fotso et al., 2009; Undie et al., 2009).

\section{Conclusions}

The author citation network analysis that has been conducted in this study, using data from Scopus for the period 1965 to 2017, has shed light on the evolution of research activity focused on urban poverty. The results indicate that publication activity on urban poverty has increased after the 1990s, with the US and the UK both leading in this research field. At the same time, publications referring to Sub-Saharan and Asian case studies illustrate a rising trend during the last decade, indicating the need for increased attention of the urban poverty challenges that these areas face. Meanwhile, the notion of urban poverty has gradually broadened, starting to encompass additional aspects related to this phenomenon, including deterioration of human health and behavioral outcomes.

Five main communities of authors have been identified within this field of study using author citation network analysis, reflecting different views relevant to urban poverty aspects. Starting from the most-populated community, it mainly focuses on defining and assessing policy interventions that could be applied towards urban poverty alleviation. This policy-oriented community has highlighted the importance of urban poverty, compared to traditional approaches that mostly focused on rural poverty aspects. Identification of possible ways to enhance institutional capabilities of the urban areas, through public participation of the urban poor, are in the spotlight of current policy debates, offering an input for further investigation in this field.

The second identified community includes authors that mostly investigate aspects of urban poverty concentration and its interactions with the growing income inequality. Different patterns of economic growth may lead to diversified negative externalities within cities, affecting spatial segregation of the urban poor. At the same time, neighboring effects arising through significant levels of poverty concentration might prevent quality-of-life improvements at a local level. To this end, the effects of intra-urban migration flows on urban concentration patterns, as well as the role of local housing markets as drivers of poverty segregation, need to be further investigated to provide additional insights for the formation processes of this phenomenon.

Authors mostly exploring the rise of poverty in Chinese cities are part of the third discrete community of the derived network, indicating that China constitutes a special case. The extensive structural changes that China has been experiencing since the late 1990s, alongside with the implementation of poverty alleviation policies based on government transfers are two essential parameters that are taken into consideration in this case. One of the main research questions that is still under investigation and is highly relevant to the recent basic income debate (Van Parijs and Vanderborght, 2017), is whether dibao-type anti-poverty programs have managed to reduce poverty rates or neighborhood effects that exist in highly urbanized areas.

The last two identified author communities relate mainly to behavioral and health aspects of urban poverty. Both cases include a smaller number of authors, constituting recently emerging fields of study. Authors included in the fourth identified community try to explore the impacts of urban poverty on human behavior, with a specific focus on children and adolescents. Under this context, there is a need to more clearly specify the existing and emerging channels between low-income environments and human betterment processes, such as educational attainment. On the other hand, authors in the fifth community investigate poverty aspects related to urban health, including mainly empirical studies from Sub-Saharan and Asian slum areas. In this case, collection of longitudinal data is a significant challenge. In both cases, the evaluation and assessment of already implemented health care policies, as well as the investigation of possible alternatives that 
could increase policy effectiveness are in the spotlight of current research, offering a fertile ground for further investigation.

In revealing the structure of the research domain, four key considerations can be proposed which should be taken into account when investigating urban poverty phenomena. Firstly, it is essential to identify the type of urbanization process under investigation, as this factor dictates the framework for the analysis. Dependent upon the context, different approaches should be used when studying urban poverty and proposing mitigation measures. Secondly, the analysis of the structural characteristics specifically relating to poverty formation, should be given high priority. These mechanisms might vary, depending on the urbanization process, in terms of labor market participation mis-functionalities or restrictions, as well as aspects of spatial fragmentation, such as residential or social segregation within cities. Thirdly, the type of urbanization process and poverty formation mechanisms play a key role in the identification of the appropriate policy interventions, as governance and institutional effectiveness are central to urban poverty research. Finally, when exploring urban poverty outcomes in relation to living conditions, it is essential to fully understand direct health aspects, such as large-scale diseases, but also indirect after-effects that might arise, in particular amongst young populations.

\section{References}

Abenavoli, R. M., Greenberg, M. T., \& Bierman, K. L. 2015. Parent support for learning at school entry: Benefits for aggressive children in high-risk urban contexts. Early Childhood Research Quarterly, 31, 9-18. https://doi.org/10.1016/j.ecresq.2014.12.003

Abubakar, I. R., \& Dano, U. L. 2018. Socioeconomic challenges and opportunities of urbanization in Nigeria. In Urbanization and Its Impact on Socio-Economic Growth in Developing Regions (pp. 219-240). IGI Global.

Adam, D. 2002. The Counting House. Nature, 415(6873), 726-729.

Adebimpe, A. A. 2013. Population dynamics and infrastructure: meeting the millennium development goals in Ondo State, Nigeria. Etude de la Population Africaine, 27(2), 229. http://dx.doi.org/10.11564/27-2-443

Ahmad, S., \& Puppim de Oliveira, J.A. 2015. Fuel Switching in Slum and Non-Slum Households in Urban India, Journal of Cleaner Production, 94, 130-136. http://dx.doi.org/10.1016/j.jclepro.2015.01.072

Alahdab, F., \& Murad, M. H. (2019). Evidence Maps: A Tool to Guide Research Agenda Setting. BMJ Evidence-Based Medicine. http://doi:10.1136/bmjebm-2018-111137.

Alexandrova, A., Hamilton, E. L., \& Kuznetsova, P. 2006. What can be learned from introducing settlement typology into urban poverty analysis: The case of the Tomsk region, Russia. Urban Studies, 43(7), 1177-1189. https://doi.org/10.1080/00420980600599109

Anakwenze, U., \& Zuberi, D. 2013. Mental health and poverty in the inner city. Health \& social work, 38(3), 147-157. https://doi.org/10.1093/hsw/hlt013

Andersson, R., \& Hedman, L. 2016. Economic decline and residential segregation: A Swedish study with focus on Malmo. Urban Geography 37[5]: 748-768. https://doi.org/10.1080/02723638.2015.1133993

Attar, B. K., Guerra, N. G., \& Tolan, P. H. 1994. Neighborhood disadvantage, stressful life events and adjustments in urban elementary-school children. Journal of Clinical Child Psychology, 23(4), 391-400. https://doi.org/10.1207/s15374424jccp2304 5

Ball, R., \& Tunger, D. 2006. Science Indicators Revisited - Science Citation Index Versus SCOPUS: A Bibliometric Comparison of Both Citation Databases. Information Services \& Use, 26, 293-301.

Bar-Ilan, J. 2018. Tale of Three Databases: The Implication of Coverage Demonstrated for a Sample Query. Frontiers in Research Metrics and Analytics, 3, 1-9. 
Beall, J. 1995. Social security and social networks among the urban poor in Pakistan. Habitat International, 19(4), 427-445. https://doi.org/10.1016/0197-3975(95)00038-H

Beall, J., Crankshaw, O., \& Parnell, S. 2000. The Causes of Unemployment in Post-apartheid Johannesburg and the Livelihood Strategies of the Poor. Tijdschrift voor economische en sociale geografie, 91(4), 379-396. https://doi.org/10.1111/1467-9663.00125

Beall, J., Goodfellow, T., \& Rodgers, D. 2013. Cities and conflict in fragile states in the developing world. Urban Studies, 50(15), 3065-3083. https://doi.org/10.1177\%2F0042098013487775

Berube, A., \& Frey, W. 2002. A Decade of Mixed Blessings. Washington, DC: Brookings Institution.

Blondel, V. D., Guillaume, J. L., Lambiotte, R., \& Lefebvre, E. 2008. Fast unfolding of communities in large networks. Journal of statistical mechanics: theory and experiment, 2008(10).

Booth, D., Holland, J., Henstchel, J., Lanjouw, P., \& Herbert, A. 1998. Participation and Combined Methods in African Poverty Assessment: Renewing the Agenda (London: Social Development Division, Department for International Development).

Brooks-Gunn, J., Klebanov, P. K., \& Liaw, F. R. 1995. The learning, physical, and emotional environment of the home in the context of poverty: The Infant Health and Development Program. Children and Youth Services Review, 17(1-2), 251-276. https://doi.org/10.1016/0190-7409(95)00011-Z

Bryant, J. J. 1993. Urban poverty and the environment in the South Pacific. University of New England.

Cappella, E., Frazier, S. L., Atkins, M. S., Schoenwald, S. K., \& Glisson, C. (2008). Enhancing schools' capacity to support children in poverty: An ecological model of school-based mental health services. Administration and Policy in Mental Health and Mental Health Services Research, 35(5), 395-409. https://doi.org/10.1007/s10488-008-0182-y

Casillas, J., \& Acedo, F. 2007. Evolution of the Intellectual Structure of Family Business Literature: A Bibliometric Study of FBR. Family Business Review, 20(2), 141-162. https://doi.org/10.1111\%2Fi.1741-6248.2007.00092.x

Cavanaugh, A., \& Breau, S. 2017. Locating geographies of inequality: publication trends across OECD countries. Regional Studies, 1-12. https://doi.org/10.1080/00343404.2017.1371292

Ceballo, R., McLoyd, V. C., \& Toyokawa, T. 2004. The influence of neighborhood quality on adolescents' educational values and school effort. Journal of Adolescent Research, 19(6), 716739. https://doi.org/10.1177\%2F0743558403260021

Chen, S., Ravallion, M., \& Wang, Y. 2006. Di Bao: A guaranteed minimum income in China's cities? (Vol. 3805). World Bank Publications.

Cheng, F., Zhang, X., \& Shenggen, F. 2002. Emergence of urban poverty and inequality in China: evidence from household survey. China Economic Review, 13(4), 430-443. https://doi.org/10.1016/S1043-951X(02)00101-3

Chigbu, U. E. 2012. Village renewal as an instrument of rural development: evidence from Weyarn, Germany. Community Development, 43(2), 209-224. https://doi.org/10.1080/15575330.2011.575231

Cho, S. H., Jung, S., Roberts, R. K., \& Kim, S. G. 2012. Interrelationship between poverty and the wildland-urban interface in metropolitan areas of the Southern US. Applied Economics, 44(11), 1405-1416. https://doi.org/10.1080/00036846.2010.541392

Clauset, A., Newman, M.E.J., \& Moore, C. 2004. Finding community structure in very large networks. Physical Review E, 70(6), 066111.

Cooke, T.J. 2010. Residential mobility of the poor and the growth of poverty in inner-ring suburbs. Urban Geography 31[2]: 179-193. https://doi.org/10.2747/0272-3638.31.2.179

Cooke, T.J., \& Denton, C. 2015. The suburbanization of poverty? An alternative perspective. Urban Geography 36[2]: 300-313. https://doi.org/10.1080/02723638.2014.973224 
Cooke, T., \& Marchant, S. 2006. The changing intrametropolitan location of high-poverty neighbourhoods in the US, 1990-2000. Urban Studies, 43(11), 1971-1989. https://doi.org/10.1080\%2F00420980600897818

Crowder, K., \& South, S. J. 2003. Neighborhood distress and school dropout: The variable significance of community context. Social Science Research, 32(4), 659-698. https://doi.org/10.1016/S0049-089X(03)00035-8

Dawkins, C. J. 2004. Measuring the spatial pattern of residential segregation. Urban Studies, 41(4), 833-851. https://doi.org/10.1080\%2F0042098042000194133

DeGelder, M. 2012. Ways of dying: AIDS care and agency in contemporary urban South Africa. Ethnography, 13(2), 189-212. https://doi.org/10.1177\%2F1466138111413502

De Bellis, N. 2009. Bibliometrics and Citation Analysis: From the Science Citation Index to Cybermetrics. Lanham, MD: The Scarecrow Press.

De Haan, A. D. 1997. Rural-Urban Migration and Poverty: The Case of India. IDS Bulletin, 28(2), 35-47. https://doi.org/10.1111/j.1759-5436.1997.mp28002004.x

De Meo, P., Ferrara, E., Fiumara, G., \& Provetti, A. 2011. Generalized Louvain method for community detection in large networks. In 2011 11th International Conference on Intelligent Systems Design and Applications (pp. 88-93). IEEE.

Devas, N. 2014. Urban governance voice and poverty in the developing world. Routledge.

Driessen, P., Vellinga, P., Van Deelen, K., Slegers, M. F. W., Döpp, S. P., Heinen, M., De Pater, F., Piek, O., \& Van Nieuwaal, K. 2015. Knowledge for Climate 2008-2014. KfC 153/2015. Foundation Knowledge for Climate.

Duch, J., \& Arenas, A. (2005). Community detection in complex networks using extremal optimization. Physical review E, 72(2), 027104.

Dubow, E. F., Tisak, J., Causey, D., Hryshko, A., \& Reid, G. 1991. A two-year longitudinal study of stressful life events, social support, and social problem-solving skills: Contributions to children's behavioral and academic adjustment. Child development, 62(3), 583-599. https://doi.org/10.1111/j.1467-8624.1991.tb01554.x

Duncan, G. J., \& Brooks-Gunn, J. 1999. Consequences of growing up poor. Russell Sage Foundation.

Durán Sánchez, A., de la Cruz Del Río Rama, M., \& Álvarez García, J. 2017. Bibliometric Analysis of Publications on Wine Tourism in the Databases Scopus and WoS. European Research on Management and Business Economics, 23, 8-15.

Earls, F. 2000. Urban poverty: Scientific and ethical considerations. The Annals of the American Academy of Political and Social Science, 572(1), 53-65. https://doi.org/10.1177\%2F000271620057200109

Ebrahim, G. J. 2008. Poverty and the Millennium Development Goals. Journal of tropical pediatrics, 54(1), 1-5.

Elsey, H., Manandah, S., Sah, D., Khanal, S., MacGuire, F., King, R., \& Baral, S. C. 2016. Public health risks in urban slums: findings of the qualitative 'healthy kitchens healthy cities' study in Kathmandu, Nepal. PloS one, 11(9). https://doi.org/10.1371/journal.pone.0163798

Emmons, S., Kobourov, S., Gallant, M., \& Börner, K. 2016. Analysis of Network Clustering Algorithms and Cluster Quality Metrics at Scale. PLOS One, 11(7), 1-18.

Evans, G. W., \& English, K. 2002. The environment of poverty: Multiple stressor exposure, psychophysiological stress, and socioemotional adjustment. Child development, 73(4), 12381248. https://doi.org/10.1111/1467-8624.00469

Evans, G. W., \& Kantrowitz, E. 2002. Socioeconomic status and health: the potential role of environmental risk exposure. Annual review of public health, 23(1), 303-331.

Feinerer, I., \& Hornik, K. 2017. Text Mining Package-Package Tm. CRAN R-Project; CRAN RProject: Vienna, Austria.

Feinerer, K. Hornik, and D. Meyer. 2008. Text mining infrastructure in R. Journal of Statistical Software, 25(5): 1-54, March 2008. ISSN 1548-7660. URL http://www.jstatsoft.org/v25/i05. 
Fortunato, S. 2010. Community detection in graphs. Physics reports, 486(3-5), 75-174.

Fotso, J. C., Holding, P. A., \& Ezeh, A. C. 2009. Factors conveying resilience in the context of urban poverty: The case of orphans and vulnerable children in the informal settlements of Nairobi, Kenya. Child and Adolescent Mental Health, 14(4), 175-182. https://doi.org/10.1111/j.1475-3588.2009.00534.x

Fox, S., \& Beall, J. 2012. Mitigating conflict and violence in African cities. Environment and Planning C: Government and Policy, 30(6), 968-981. https://doi.org/10.1068\%2Fc11333j

Fox, S., \& Goodfellow, T. 2016. Cities and Development. Routledge.

Frazier, S. L., Dinizulu, S. M., Rusch, D., Boustani, M. M., Mehta, T. G., \& Reitz, K. 2015. Building resilience after school for early adolescents in urban poverty: Open trial of Leaders@ Play. Administration and Policy in Mental Health and Mental Health Services Research, 42(6), 723736. https://doi.org/10.1007/s10488-014-0608-7

Friedrichs, J. R., Galster, G.C., \& Musterd, S. 2003. Neighbourhood effects on social opportunities: the European and American research and policy context. Housing studies, 18(6), 797-806. https://doi.org/10.1080/0267303032000156291

Galster, G.C. 1987. Residential segregation and interracial economic disparities: A simultaneousequations approach. Journal of Urban Economics, 21(1), 22-44. https://doi.org/10.1016/00941190(87)90020-9

Galster, G.C. 2005. Consequences from the redistribution of urban poverty during the 1990s: A cautionary tale. Economic Development Quarterly, 19(2), 119-125. https://doi.org/10.1177\%2F0891242404273981

Galster, G.C. 2007. Neighbourhood social mix as a goal of housing policy: a theoretical analysis. International Journal of Housing Policy, 19-43. https://doi.org/10.1080/14616710601132526

Galster G.C. (2012) The Mechanism(s) of Neighbourhood Effects: Theory, Evidence, and Policy Implications. In: van Ham M., Manley D., Bailey N., Simpson L., Maclennan D. (eds) Neighbourhood Effects Research: New Perspectives. Springer, Dordrecht. https://doi.org/10.1007/978-94-007-2309-2 2

Galster, G.C., \& Mincy, R.B. 1993. Understanding the changing fortunes of metropolitan neighborhoods, 1980 to 1990. Housing Policy Debate, 4(3), 303-352. https://doi.org/10.1080/10511482.1993.9521136

Gilbert, A. 1995. Debt, poverty and the Latin American city. Geography, 80(4), pp.323-333.

Giles, J., Park, A., \& Wang, M. 2008. The great proletarian Cultural Revolution, disruptions to education, and returns to schooling in urban China. World Bank.

Glänzel, W., \& Thijs, B. 2017. Using Hybrid Methods and 'core Documents' for the Representation of Clusters and Topics: The Astronomy Dataset. Scientometrics, 11, 1071-1087.

Gómez-Núnez, A. J., Batagelj, V., Vargas-Quesada, B., Moya-Anegón, F., \& ChinchillaRodríguez, Z. 2014. Optimizing SCImago Journal \& Country Rank Classification by Community Detection. Journal of Informetrics, 8, 369-383.

Gonzales, N. A., Cauce, A. M., Friedman, R. J., \& Mason, C. A. 1996. Family, peer, and neighborhood influences on academic achievement among African-American adolescents: One-year prospective effects. American journal of community psychology, 24(3), 365. https://doi.org/10.1007/BF02512027

Grott, R., Hoogerwerf, E., MacLachlan, M., Teunissen, L., de Witte, L., \& Borg, J. 2017. Global Priority Research Agenda for Improving Access to High-quality Affordable Assistive Technology. World Health Organization.

Guimerà, R., Sales-Pardo, M., \& Amaral, L. A. N. 2004. Modularity from fluctuations in random graphs and complex networks. Physical Review E, 70(2), 025101.

Gulyani, S., \& Talukdar, D. 2010. Inside informality: The links between poverty, microenterprises, and living conditions in Nairobi's slums. World Development, 38(12), 1710-1726. https://doi.org/10.1016/j.worlddev.2010.06.013 
Gusenbauer, M. 2019. Google Scholar to Overshadow Them All? Comparing the Sizes of 12 Academic Search Engines and Bibliographic Databases. Scientometrics, 118(1), 177-214.

Gustafsson, B., \& Zhong, W. 2000. How and why has poverty in China changed? A study based on microdata for 1988 and 1995. The China Quarterly, 164, 983-1006. https://doi.org/10.1017/S0305741000019263

Haddad, L., Hawkes, C., Webb, P., Thomas, S., Beddington, J., Waage, J., \& Flynn, D. 2016. A New Global Research Agenda for Food. Nature, 540, 30-32.

Haddad, L., Ruel, M. T., \& Garrett, J. L. 1999. Are urban poverty and undernutrition growing? Some newly assembled evidence. World development, 27(11), 1891-1904. https://doi.org/10.1016/S0305-750X(99)00093-5

Haddaway, N. R., Collins, A. M., Coughlin, D., \& Kirk, S. (2015). The Role of Google Scholar in Evidence Reviews and Its Applicability to Grey Literature Searching. PLoS ONE, 10(9), 1-17.

Halevi, G., Moed, H., \& Bar-Ilan, J. 2017. Suitability of Google Scholar As a Source of Scientific Information and As a Source of Data for Scientific Evaluation - Review of the Literature. Journal of Informetrics, 11(3), 823-834.

Hanefeld, J., Vearey, J., \& Lunt, N. 2017. A Global Research Agenda on Migration, Mobility, and Health. The Lancet, 389(1878), 2358-2359.

Hardoy, J., \& Pandiella, G. 2009. Urban poverty and vulnerability to climate change in Latin America. Environment and Urbanization, 21(1), 203-224. https://doi.org/10.1177\%2F0956247809103019

Harpham, T., \& Stephens, C. 1991. Urbanization and health in developing countries. World health statistics quarterly. Rapport trimestriel de statistiques sanitaires mondiales, 44(2), 62-69.

Hassan, S. U., Haddawy, P., \& Zhu, J. 2014. A bibliometric study of the world's research activity in sustainable development and its sub-areas using scientific literature. Scientometrics, 99(2), 549-579. https://doi.org/10.1007/s11192-013-1193-3

Hentschel, J. 2004. Using rapid city surveys to inform municipal social policy: an application in Cali, Colombia (Vol. 3369). World Bank Publications.

Hentschel, J., \& Seshagiri, R. 2000. The City Poverty Assessment: A Primer (Vol. 490). World Bank Publications.

Hilson, G., Gillani, A., \& Kutaula, S. 2018. Towards Sustainable Pro-Poor Development? A Critical Assessment of Fair Trade Gold. Journal of Cleaner Production, 186, 894-904. https://doi.org/10.1016/j.jclepro.2018.03.123

Hunter, M. 2007. The changing political economy of sex in South Africa: The significance of unemployment and inequalities to the scale of the AIDS pandemic. Social science \& medicine, 64(3), 689-700. https://doi.org/10.1016/j.socscimed.2006.09.015

Hunter, P. 2014. Poverty in suburbia: A Smith Institute study into the growth of poverty in the suburbs of England and Wales. The Smith Institute.

Jacomy, M., Venturini, T., Heymann, S., \& Bastian, M. 2014. ForceAtlas2, a continuous graph layout algorithm for handy network visualization designed for the Gephi software. PloS one, 9(6). https://doi.org/10.1371/journal.pone.0098679

Jargowsky P. A. 1996. Beyond the street corner: The hidden diversity of high-poverty neighborhoods. Urban Geography 17(7), pp. 579-603. https://doi.org/10.2747/0272$\underline{3638.17 .7 .579}$

Jargowsky, P. A. 2002. Sprawl, concentration of poverty, and urban inequality. Urban sprawl: Causes, consequences, and policy responses, pp.39-72.

Jha, Darshan and Tripathi, V., Achieving Millennium Development Goals and India Vision 2020: Evidences from the Slums of Varanasi City (April 22, 2015). Space \& Culture, India, Vol. 2, No. 4, 2015. Available at SSRN: https://ssrn.com/abstract $=2597833$

Kaserman, A., Shyu, S., \& Lu, J. 2015. Homelessness and Urban Sprawl of Large Cities of the US. In GLOBAL MODERNIZATION REVIEW: New Discoveries and Theories Revisited (pp. 137-145). 
Khan, A. R., \& Riskin, C. 2001. Inequality and Poverty in China in the Age of Globalization. Oxford University Press.

Kimani-Murage, E. W., Muthuri, S. K., Oti, S. O., Mutua, M. K., van de Vijver, S., \& Kyobutungi, C. 2015. Evidence of a double burden of malnutrition in urban poor settings in Nairobi, Kenya. PloS one, 10(6). https://doi.org/10.1371/journal.pone.0129943

Kingsley, G. T., \& Pettit, K. L. 2003. Concentrated poverty: A change in course.

Kneebone, E., \& Berube, A. 2013. Confronting suburban poverty in America. Brookings Institution Press.

Knight, J., \& Xue, J. 2006. How high is urban unemployment in China? Journal of Chinese Economic and Business Studies, 4(2), 91-107. https://doi.org/10.1080/14765280600736833

Knight, J. and Song, L. 2005. Towards a Labour Market in China, Oxford: Oxford University Press.

Knight, J., \& Shi, L. 2016. Three poverties in urban China. In SEEKING CHANGES: The Economic Development in Contemporary China (pp. 113-144).

Lanjouw, P., \& Murgai, R. 2010. Urban growth and poverty in India, 1983-2005. Economic Reform in India: Challenges, Prospects, and Lessons, 371-402. https://dx.doi.org/10.1017/cbo9781139096638.014

Lee, J., Gross, S. P., \& Lee, J. 2012. Modularity optimization by conformational space annealing. Physical Review E, 85(5), 056702.

Lehmann, S., \& Hansen, L. K. 2007. Deterministic modularity optimization. The European Physical Journal B, 60(1), 83-88.

Liu, Y., He, S., Wu, F., \& Webster, C. 2010. Urban villages under China's rapid urbanization: unregulated assets and transitional neighbourhoods. Habitat International, 34(2), 135-144. https://doi.org/10.1016/i.habitatint.2009.08.003

López-Morales, E. 2016. Gentrification in Santiago, Chile: a property-led process of dispossession and exclusion. Urban Geography, 37(8), 1109-1131. https://doi.org/10.1080/02723638.2016.1149311

Lorant, V., Deliège, D., Eaton, W., Robert, A., Philippot, P., \& Ansseau, M. 2003. Socioeconomic inequalities in depression: a meta-analysis. American journal of epidemiology, 157(2), 98-112. https://doi.org/10.1093/aje/kwf182

Ludwig, J., Duncan, G. J., \& Hirschfield, P. 2001. Urban poverty and juvenile crime: Evidence from a randomized housing-mobility experiment. The Quarterly Journal of Economics, 116(2), 655-679. https://doi.org/10.1162/00335530151144122

Ludwig, J., Duncan, G. J., \& Pinkston, J. C. 2005. Housing mobility programs and economic selfsufficiency: Evidence from a randomized experiment. Journal of Public Economics, 89(1), 131156. https://doi.org/10.1016/j.jpubeco.2003.07.010

Ma, R. 2012. Author bibliographic coupling analysis: A test based on a Chinese academic database. Journal of Informetrics, 6(4), 532-542. https://doi.org/10.1016/j.joi.2012.04.006

Magadi, M. A. 2013. The disproportionate high risk of HIV infection among the urban poor in subSaharan Africa. AIDS and Behavior, 17(5), 1645-1654. https://doi.org/10.1007/s10461-0120217-y

Magadi, M. A. 2016. Understanding the urban-rural disparity in HIV and poverty nexus: the case of Kenya. Journal of Public Health, 39(3), pp.63-72. https://doi.org/10.1093/pubmed/fdw065

Martín-Martín, A., Orduna-Malea, E., \& Delgado López-Cózar, E. 2018. Coverage of Highly-cited Documents in Google Scholar, Web of Science, and Scopus: A Multidisciplinary Comparison. Scientometrics, 116(3), 2175-2188.

Massey, D. S., Gross, A. B., \& Eggers, M. L. 1991. Segregation, the concentration of poverty, and the life chances of individuals. Social Science Research, 20(4), 397-420. https://doi.org/10.1016/0049-089X(91)90020-4

Massey, D. S., \& Denton, N. A. 1993. American apartheid: Segregation and the making of the underclass. Harvard University Press. 
Massey, D. S., Gross, A. B., \& Shibuya, K. 1994. Migration, segregation, and the geographic concentration of poverty. American Sociological Review, 59(3), pp.425-445. https://www.jstor.org/stable/2095942

Maxwell, D. 1999. The political economy of urban food security in Sub-Saharan Africa. World Development, 27(11), 1939-1953. https://doi.org/10.1016/S0305-750X(99)00101-1

McFarlane, C., Desai, R., \& Graham, S. 2014. Informal urban sanitation: Everyday life, poverty, and comparison. Annals of the Association of American Geographers, 104(5), 989-1011. https://doi.org/10.1080/00045608.2014.923718

McGranahan, G. 1991. Environmental problems and the urban household in third world countries. Stockholm Environment Institute.

McGranahan, G. 2015. Realizing the right to sanitation in deprived urban communities: meeting the challenges of collective action, coproduction, affordability, and housing tenure. World Development, 68, 242-253. https://doi.org/10.1016/j.worlddev.2014.12.008

McMahon, T. J., \& Luthar, S. S. 2007. Defining characteristics and potential consequences of caretaking burden among children living in urban poverty. American Journal of Orthopsychiatry, 77(2), 267-281. https://doi.org/10.1037/0002-9432.77.2.267

McSweeney, P. J. 2009. Gephi network statistics. Google Summer of Code, 1-8.

Meerow, S., Newell, J. P., \& Stults, M. 2016. Defining urban resilience: A review. Landscape and urban planning, 147, 38-49. https://doi.org/10.1016/j.landurbplan.2015.11.011

Meng, X., Gregory, R., \& Wang, Y. 2005. Poverty, inequality, and growth in urban China, 19862000. Journal of Comparative Economics, 33(4), 710-729. https://doi.org/10.1016/i.jce.2005.08.006

Meng, X., Gregory, R., \& Wan, G. 2007. Urban poverty in China and its contributing factors, 19862000. Review of Income and Wealth, 53(1), 167-189.

Mitlin, D. 2003. Addressing urban poverty through strengthening assets. Habitat International, 27(3), 393-406. https://doi.org/10.1016/S0197-3975(02)00066-8

Mondi, C. F., Reynolds, A. J., \& Ou, S. R. 2017. Predictors of depressive symptoms in emerging adulthood in a low-income urban cohort. Journal of applied developmental psychology, 50, 4559. https://doi.org/10.1016/j.appdev.2017.03.009

Mongeon, P., \& Paul-Hus, A. 2016. The Journal Coverage of Web of Science and Scopus: A Comparative Analysis. Scientometrics, 106(1), 213-228.

Mora, L., \& Deakin, M. 2019. Untangling Smart Cities: From Utopian Dreams to Innovation Systems for a Technology-Enabled Urban Sustainability. Amsterdam: Elsevier.

Mora, L., Bolici, R., \& Deakin, M. 2017. The First Two Decades of Smart-City Research: A Bibliometric Analysis. Journal of Urban Technology, 24(1), 1-25. https://doi.org/10.1080/10630732.2017.1285123

Mora, L., Deakin, M., \& Reid, A. 2019. Combining Co-Citation Clustering and Text-Based Analysis to Reveal the Main Development Paths of Smart Cities. Technological Forecasting and Social Change, 142, 56-69.

Moser, C. 1996. Confronting crisis: a comparative study of household responses to poverty and vulnerability in four poor urban communities.

Moser, C. 1998. The Asset Vulnerability Framework: Reassessing Urban.

Moser, C., Herbert, Aj. and Makonnen, R, E. 1993. Urban poverty in the context of structurai adjustment; recent evidence and policy responses. TWU Discussion Paper No 4, Urban Development Division, Washington DC: World Bank.

Murali, V., \& Oyebode, F. 2004. Poverty, social inequality, and mental health. Advances in Psychiatric Treatment, 10, 216-224. https://doi.org/10.1192/apt.10.3.216

Musterd, S. 2005. Social and ethnic segregation in Europe: levels, causes, and effects. Journal of urban affairs, 27(3), 331-348. https://doi.org/10.1111/j.0735-2166.2005.00239.x 
Musterd, S., Marcińczak, S., van Ham, M., \& Tammaru, T. 2017. Socioeconomic segregation in European capital cities. Increasing separation between poor and rich. Urban Geography, 38(7), 1062-1083. https://doi.org/10.1080/02723638.2016.1228371

Musterd, S., Murie, A., \& Kesteloot, C. 2016. Neighbourhoods of poverty. Palgrave Macmillan.

Newman, M. E. 2004a. Fast algorithm for detecting community structure in networks. Physical review $\mathrm{E}, 69(6), 066133$.

Newman, M. E. 2004b. Analysis of weighted networks. Physical review E, 70(5), 056131.

Newman, M. E. 2006a. Finding community structure in networks using the eigenvectors of matrices. Physical review E, 74(3), 036104.

Newman, M. E. 2006b. Modularity and community structure in networks. Proceedings of the national academy of sciences, 103(23), 8577-8582.

Ngigi, M. M. 2007. AIDS and the city: Exploring the spatial characteristics of HIVIAIDS pandemic in Nairobi, Kenya. Geographical Review of Japan, 80(12), 789-803. https://doi.org/10.4157/gri.80.789

Niekler, A., Wiedemann, G., \& Heyer, G. 2014. Leipzig Corpus Miner - A text mining infrastructure for qualitative data analysis. In Terminology and knowledge engineering 2014 (TKE 2014). Berlin.

Olvera, L. D. 2005. Is the City beyond Reach? Walking, Access to Services and Spatial Segregation in Sub-Saharan Africa. Space populations societies, (1), 145-161.

Pacione M. 2004 Environments of disadvantage: Geographies of persistent poverty in Glasgow. Scottish Geographical Journal 120: 117-132. https://doi.org/10.1080/00369220418737196

Porter, M. A., Onnela, J. P., \& Mucha, P. J. 2009. Communities in networks. Notices of the AMS, 56(9), 1082-1097.

Pryer, J. A. 2017. Poverty and vulnerability in Dhaka slums: the urban livelihoods study. Routledge.

Rakodi, C. 1995. Poverty lines or household strategies? A review of conceptual issues in the study of urban poverty. Habitat International, 19(4), 407-426. https://doi.org/10.1016/01973975(95)00037-G

Ravallion, M. 2002. On the urbanization of poverty. Journal of Development Economics, 68(2), 435-442. https://doi.org/10.1016/S0304-3878(02)00021-4

Ravallion, M. 2007. Urban poverty. Finance and Development, 44(3), 15-17.

Raleigh, C. (2015). Urban violence patterns across African states. International Studies Review, 17(1), 90-106. https://doi.org/10.1111/misr.12206

Reichardt, J., \& Bornholdt, S. 2006. Statistical mechanics of community detection. Physical Review E, 74(1), 016110.

Riskin, C., \& Gao, Q. 2009. The changing nature of urban poverty in China. Debates in the Measurement of Poverty. Oxford University Press, Oxford.

Rodrigo, C., \& Rajapakse, S. 2010. HIV, poverty and women. International Health, 2(1), 9-16. https://doi.org/10.1016/j.inhe.2009.12.003

Rosni, N. A., \& Noor, A. P. 2016. A review of literature on urban sprawl: assessment of factors and causes. Journal of Architecture, Planning and Construction Management, 6(1). Retrieved from http://journals.iium.edu.my/kaedjournal/index.php/KAEDJournals/article/view/193

Ruel, M. T. 2000. Urbanization in Latin America: constraints and opportunities for child feeding and care. Food and Nutrition Bulletin, 21(1), 12-24. https://doi.org/10.1177\%2F156482650002100103

Sassen, S. 1991. The Global City: New York. London, Tokyo.

Satterthwaite, D. 1997. Urban poverty: reconsidering its scale and nature. IDS bulletin, 28(2), 923. https://doi.org/10.1111/j.1759-5436.1997.mp28002002.x

Satterthwaite, D. 2003a. The Millennium Development Goals and urban poverty reduction: great expectations and nonsense statistics. Environment and urbanization, 15(2), 179-190. https://doi.org/10.1177\%2F095624780301500208 
Satterthwaite, D. 2003b. The links between poverty and the environment in urban areas of Africa, Asia, and Latin America. The Annals of the American Academy of Political and Social Science, 590(1), 73-92. https://doi.org/10.1177\%2F0002716203257095

Schopfel, J. 2010. Towards a Prague Definition of Grey Literature. In D. J. Farace, \& J. Fratzen (Eds.), Twelfth International Conference on Grey Literature: Transparency in Grey Literature. Grey Tech Approaches to High Tech Issues, Prague, 6-7 December 2010 (pp. 11-26). TextRelease.

Scott, A.J., \& Storper, M. 2015. The nature of cities: the scope and limits of urban theory. International Journal of Urban and Regional Research, 39(1), 1-15. https://doi.org/10.1111/1468-2427.12134

Shultz, M. 2007. Comparing Test Searches in PubMed and Google Scholar. Journal of the Medical Library Association, 95(4), 442-453.

Small, H. G., \& Crane, D. 1979. Specialties and Disciplines in Science and Social Science: An Examination of Their Structure Using Citation Indexes. Scientometrics, 1(5-6), 445-461. https://doi.org/10.1007/BF02016661

Small, H. G., \& Griffith, B. C. 1974. The Structure of Scientific Literature I: Identifying and Graphing Specialties. Science Studies, 4(1), 17-40. https://doi.org/10.1177\%2F030631277400400102

Small, M.L., \& Newman, K. 2001. Urban poverty after the truly disadvantaged: The rediscovery of the family, the neighborhood, and culture. Annual Review of sociology, 27(1), 23-45. https://doi.org/10.1146/annurev.soc.27.1.23

Stein, A., \& Horn, P. 2012. Asset accumulation: an alternative approach to achieving the millennium development goals. Development Policy Review, 30(6), 663-680. https://doi.org/10.1111/j.1467-7679.2012.00593.x

Sweileh, W.M., Al-Jabi, S.W., Sawalha, A.F., AbuTaha, A.S., \& Sa'ed, H.Z. 2016. Bibliometric analysis of medicine-related publications on poverty (2005-2015). SpringerPlus, 5(1), 1888. https://doi.org/10.1186/s40064-016-3593-3

Tabatabai, H. and Fouad, M. 1993. The Incidence of Poverty in Developing Countries: An ILO Compendium of Data, A World Employment Programme Study, Geneva: International Labour Office.

Tacoli, C., Bukhari, B., \& Fisher, S. 2013. Urban poverty, food security and climate change. Human Settlements Group, International Institute for Environment and Development (IIED).

Tammaru, T., Musterd, S., Van Ham, M., \& Marcińczak, S. 2016. A multi-factor approach to understanding socio-economic segregation in European capital cities. Taylor \& Francis.

United Nations. 1996. Global report on human settlements, 1996. UN HABITAT.

United Nations. 1996. An urbanizing world: Global report on human settlements, 1996.

United Nations. 2000. United Nations millennium declaration. General Assembly.

United Nations. 2001. Cities in a globalizing world: Global report on human settlements, 2001.

United Nations. 2003. The challenge of slums: Global report on human settlements, 2003.

United Nations. 2005. Financing urban shelter: Global report on human settlements, 1996.

United Nations. 2015. Transforming our World: The 2030 Agenda for Sustainable Development.

United Nations. 2017. New Urban Agenda.

Undie, C. C., Ziraba, A. K., Madise, N., Kebaso, J., \& Kimani-Murage, E. 2009. 'If you start thinking positively, you won't miss sex': narratives of sexual (in) activity among people living with HIV in Nairobi's informal settlements. Culture, health \& sexuality, 11(8), 767-782. https://doi.org/10.1080/13691050903105031

van de Vijver, S., Oti, S.O., Gomez, G.B., Agyemang, C., Egondi, T., van Charante, E.M., Brewster, L.M., Hankins, C., Tanovic, Z., Ezeh, A. and Kyobutungi, C. 2016. Impact evaluation of a community-based intervention for prevention of cardiovascular diseases in the slums of Nairobi: the SCALE-UP study. Global health action, 9(1), p.30922. https://doi.org/10.3402/gha.v9.30922 
Van Parijs, P., \& Vanderborght, Y. 2017. Basic income: A radical proposal for a free society and a sane economy. Harvard University Press.

Vearey, J., Richter, M., Núñez, L., \& Moyo, K. 2011. South African HIVIAIDS programming overlooks migration, urban livelihoods, and informal workplaces. African Journal of AIDS Research, 10(sup1), 381-391. https://doi.org/10.2989/16085906.2011.637741

Villaveces, A., Christiansen, A., \& Hargarten, S. W. 2010. Developing a Global Research Agenda on Violence and Injury Prevention: A Modest Proposal. Injury Prevention, 16, 190-193.

Waltman, L., \& Van Eck, N. J. 2013. A smart local moving algorithm for large-scale modularitybased community detection. The European Physical Journal B, 86(11), 471. https://doi.org/10.1140/epjb/e2013-40829-0

Wang, M. 2007. Emerging urban poverty and effects of the Dibao program on alleviating poverty in China. China \& World Economy, 15(2), 74-88. https://doi.org/10.1111/j.1749124X.2007.00062.x

Wang, F., Qiu, J., \& Yu, H. 2012. Research on the cross-citation relationship of core authors in scientometrics. Scientometrics, 91(3), 1011-1033. https://doi.org/10.1007/s11192-012-0621-0

Wang, P. S., Lane, M., Olfson, M., Pincus, H. A., Wells, K. B., \& Kessler, R. C. 2005. Twelvemonth use of mental health services in the United States: results from the National Comorbidity Survey Replication. Archives of general psychiatry, 62(6), 629-640. https://doi.org/10.1001/archpsyc.62.6.629

Wiedemann, G. 2016. Summary: Integrating Qualitative and Computational Text Analysis. In Text Mining for Qualitative Data Analysis in the Social Sciences (pp. 251-260). Springer VS, Wiesbaden.

Wilson, W. J. 1987. The truly disadvantaged: The inner city, the underclass, and public policy. University of Chicago Press.

Wilson, W. J. 1999. When work disappears: New implications for race and urban poverty in the global economy. Ethnic and Racial Studies, 22(3), 479-499. https://doi.org/10.1080/014198799329396

Wolffers, I., \& Adjei, S. 1999. Research-agenda Setting in Developing Countries. The Lancet, 353(9171), 2248-2249.

Wratten, E. 1995. Conceptualizing urban poverty. Environment and urbanization, 7(1), 11-38. https://doi.org/10.1177\%2F095624789500700118

Wu, F. 2004. Urban poverty and marginalization under market transition: the case of Chinese cities. International Journal of Urban and Regional Research, 28(2), 401-423. https://doi.org/10.1111/j.0309-1317.2004.00526.x

Wu, F., \& Huang, N. 2007. New urban poverty in China: Economic restructuring and transformation of welfare provision. Asia Pacific Viewpoint, 48(2), 168-185. https://doi.org/10.1111/j.1467-8373.2007.00343.x

Wu, F., He, S., \& Webster, C. 2010a. Path dependency and the neighbourhood effect: urban poverty in impoverished neighbourhoods in Chinese cities. Environment and Planning A, 42(1), 134-152. https://doi.org/10.1068\%2Fa4264

Wu, F., Webster, C., He, S., \& Liu, Y. 2010b. Urban poverty in China. Edward Elgar Publishing.

Yu, D., Wang, W., Zhang, S., Zhang, W., \& Liu, R. 2017. Hybrid Self-optimized Clustering Model Based on Citation Links and Textual Features to Detect Research Topics. PLOS One, 12(10), 1-21.

Xue, J., and Zhong W. 2004. Poverty and unemployment in urban China. China Labor Economics, 1(1), 58-71.

Zeng, C., Liu, Y., Liu, Y., \& Qiu, L. 2014. Urban sprawl and related problems: Bibliometric analysis and refined analysis from 1991 to 2011. Chinese geographical science, 24(2), 245-257. https://doi.org/10.1007/s11769-013-0619-4 
Zuccala, A., \& Van Eck, N. J. 2011. Poverty research in a development policy context. Development Policy Review, 29(3), 311-330. https://doi.org/10.1111/j.1467$\underline{\text { 7679.2011.00535.x }}$ 